\title{
Diversity in Science Education: Its Role in the Development of Latin America in the 21st Century
}

\section{Assefaw Tewolde}

\section{Introduction}

OVER THE NEXT quarter century, the world's population is expected to grow by an unprecedented 90 million people-the equivalent of Mexico's population in 1995 (IFPRI, 1996). The resulting strain on food supplies, agricultural production, services and the environment will pose enormous challenges to even the most resourceful leaders. However, a growing body of research shows that these challenges can be met provided that well-planned science education and research is in place. That being so, there still is wide variation in the levels of literacy between the different Latin American countries, indicating the differential effect that science education has on the region. This is probably due to the differential investment in science that countries have made over the years. For example, while Costa Rica, Uruguay, Argentina, and Chile are among the countries with the highest literacy rates in South America, there are other countries in the same continent with literacy rates at levels below 75 percent.

The picture is even less bright if one considers statistics of education at the postgraduate level. For example, in Mexico, only 10 percent of those who finish undergraduate education attend graduate school, and of these, less than I percent successfully complete their graduate degrees (ANUIES, 1993). Such a trend can also be observed in other countries of the region when one compares the number of scientists available per million of inhabitants in Latin America with that of scientists in the developed world. In 1990, the developed world had about 3,500 scientists per million inhabitants, while Latin America had about only 300 per million inhabitants, indicating a 1:10 ratio (Our Common Future, 1993). This shows the effort that has to be made to promote science education in Latin America to successfully meet the 
challenges of the next century. Of course, such a discrepancy can be explained in part by the fact that industrialized countries have been able to invest in science and technology much more than the rest of the world. For example, the industrialized world invested approximately 3 percent of its GNP in research and technology in 1990, while Latin America invested only 0.25 percent of its GNP (Keating, 1993). In fact, when one compares the percent of GNP spent by Latin America in science and technology in 1980 vs. 1990, it Is clear that it decreased from almost 0.3 percent in 1980 to 0.25 percent in 1990, in part due to the economic crisis that swept the region in that decade. In that same period, Asian countries almost doubled their percent of GNP spending in science and technology (from 0.4 percent in 1980 to 0.8 percent in 1990), while that of Africa remained still low and unchanged at 0.25 percent level of its GNP.

It should also be noted that Latin America has diverse agroecological, social, and anthropological aspects that should contribute to the diversification of science education for development. This will invariably mean that indigenous knowledge and science could contribute to enhancing integrated and sustained growth and development; that is, directing science education for development while at the same time ensuring the conservation of natural resources and culture.

Latin America, like the rest of the world, will not escape the challenges of the twenty-first century. These challenges include: an ever increasing concern for environmental conservation and the management of biodiversity; the globalization of the economy; and the increasing need to ensure food security to the growing population in general and particularly to the urban sector. This means that science education must focus on these challenges. In all these, science has had, and will continue to have, significant influence.

\section{Diversity in Science Education}

Diversity in science education in Latin America must be understood in terms of socioanthropology, ecology, economic development, and poverty. Each one of these elements needs to benefit from the application of science. For example, poverty at the global level, which is 
greater in the developing world, is the single most important cause for the rampant environmental degradation that is taking place and will continue to take place. It will not be possible to put in place measures affecting environmental conservation alone, as some organizations or institutions have done, without tackling rural poverty. It is in this sense that education can make a significant contribution as it has done so far at the global level.

It is increasingly evident that indigenous science can play a role in facilitating the development of society. For this to happen, culturespecific science education should be encouraged. Distinctions should be made between indigenous knowledge and present-day science, and science should be recognized and aimed at societies on a culturespecific basis. In this sense science education can be varied and at the same time effective.

On the other hand, it can be argued that science itself should be diversified enough to address different issues and problems facing society. Ultimately, it will have to focus on trying to contribute solutions to the problems previously mentioned. In Latin America and the Caribbean, the educational system varies from traditional classroom/laboratory instruction to hands-on practical work experience accompanied by class lectures. In addition, several institutions, such as those in Mexico (e.g., Universidad Aut6noma de Tamaulipas), Costa Rican national universities, or other South American universities, allow their undergraduate students to undertake a period of in-service training prior to their graduation so that they get exposure to real-world problems. However, in most institutions in the region the depth of scientific research is such that students are limited in what they can learn from these experiences. This is partly a consequence of the limited number of scientists available and institutional policies that frequently undermine research initiatives. Integrating a strong research agenda and the training of students could greatly facilitate technology transfer to communities that are served by these institutions. 
Evolution of Science Education and its Influence on Development, Especially on Agricultural Development

Science has greatly contributed to development through higher education and training in Latin America and has had a positive influence on society. However, as viewed from the perspective of agricultural and natural resources, science has had a different focus and emphasis depending on the period of development. In the 1950s, emphasis was on teaching and equipping students with scientific technologies and ideas in order to increase the production levels of crops and livestock based on research results generated primarily under experimental station conditions. In the 1960s, while still maintaining the objectives of the 1950s, the emphasis was on generating and validating technologies under producer conditions on a disciplinary basis, without the producer being the active participant in the process. In the 1970s, on the other hand, a systems approach to research was heavily emphasized, but its emphasis in higher education was not generalized, with the exception of a few institutions that incorporated them as part of their curriculum. Nevertheless, the emphasis was also on production incorporating certain sociological components into the process. The 1980 s promoted the participation of agricultural producers in the whole process of technology generation and transfer, and the objective then became productivity. In the 1990s, additional components (such as economic and managerial aspects and environmental issues) were accorded greater importance not only in the developmental process but also in the higher education system of the region, while still maintaining productivity, hence sustainability, as the main objective (Tewolde, 1993). Each one of these phases clearly signals the importance that the region has placed on science education for development. However, the concern for productivity, environmental issues, natural resources and the economics of production did not become a part of the scientific agenda until later. 'Similarly scientific research for development in Latin America, and the education that has gone with it, did not fully address issues related to the environment, gender or socioanthropological issues. 
The Paradigm of the Twenty-First Century and Its Influence on Higher Education

The century about to unfold reveals certain paradigms that must be considered, while still making use of the enormous scientific development that society has witnessed and enjoyed in the twentieth century. The most important paradigms include the following:

a. The globalization of the economy and the reduction of the role of governments in the definition and execution of programs. These components show the need for training and equipping human resources with broad-based scientific knowledge capable of handling global issues and minimizing cultural and linguistic barriers. This means that additional language besides Spanish or Portuguese (in Latin America) should be recognized as essential parts of the curriculum, even in elementary and secondary schools. A good example of this is the action taken by the government of Costa Rica three years ago when it promoted the instruction of English as early as in the elementary and secondary school systems. Also, the exchange of students and professors between or within countries will greatly facilitate the sharing of scientific technology at a much lower cost and greater ease.

b. Conservation of the environment, natural resources, and biodiversity will have to be an essential part of the next century's agenda, as was widely shown during the earth summit held in Rio de Janeiro (Our Common Future, 1993). It is a well-known fact that most of the needs of societies, such as food, clothing, medicine, and leisure, have been served by the different components of biodiversity (CATIE, 1992), even though this century has also witnessed significant genetic loss or erosion. Unless urgent measures on conservation are put in place, it will be tragic to observe the loss of certain genetic resources that could otherwise meet the demands of the next century (Hodges, 1984). Educating and training people are an important part of conservation activities, Conservation is closely tied to the alleviation of poverty in almost all countries of the world, and Latin America is no exception to that; hence the value and need for science education to be focused toward conservation and management of biodiversity.

The role that indigenous knowledge or indigenous science can play and the participation of women in development should be greatly 
emphasized. The latter has in fact been neglected to a large extent. It is probably this part of the paradigm that will influence us most in the twenty-first century.

c. Advances in biotechnology will greatly influence society's capacity to handle constraints. Educational sciences should incorporate research and teaching in this area. This field has already shown the marvelous changes it can make in living organisms, which is very promising for the twenty-first century. Biotechnological components, such as gene slicing, splitting, and hybridization at the DNA level, are only some of the avenues worth recognizing.

d. Advances in information systems and technology. The twentieth century has witnessed the impact of this technology at all levels of society worldwide, and its great influence on education and research. Today's advances have made people use the term "global village". Despite these developments, not all sectors of society in many countries enjoy such benefits. One way of ensuring that society is introduced to this technology is by creating mechanisms that can allow wider use of such technologies at educational levels. Several governments and institutions are advancing in this area, making it possible to launch long-distance education using teleconferencing. There are some excellent advances in this area taking place in Latin America, such as the one at the Universidad Aut6noma de Tamaulipas in Mexico, where information systems are well placed to serve all sectors of the community, including scholars and students. Another example is Costa Rica, where scholars and students are exempted from taxes in the purchase of hard- and software components of information technology.

e. The new society, much more urbanized, will demand a level of goods and services that is different from what the rural sector has demanded. The urbanization of society will require the reorganization of resources -and new standards of quality that should be addressed by science.

\section{Implications for Science Education}

If it is agreed that the above paradigms are going to set the stage for the next century, it is necessary to give careful consideration to the implications of these paradigms in science education and incorporate 
them into the different action plans for the development of institutions and governments. The major implications that can be foreseen, at least for Latin America, are the need to review the curricula of educational systems to ensure that students are equipped with the knowledge and talents to face the challenges of economic globalization and concern for the environment and biodiversity, while ensuring the participation of different classes of society in these endeavors.

It is important to emphasize the challenges of higher education as they apply to Latin America. These are the following:

a. Preparing people for high-level scientific, technical, professional, and managerial jobs. Especially important is the preparation of teachers, scholars, and managers for the education sector itself. This is possible only if institutions have interdependent research and education agendas that can be imitated by future scholars and teachers.

b. Generating the knowledge and innovation needed for development through indigenous scientific research and as agents of acquisition, adaptation, and dissemination of scientific and technical knowledge developed elsewhere.

c. Providing necessary services needed for development in both the public and private sectors through outreach programs.

d. Preparing individuals who can integrate issues related to the environment, economic management, and quality in the execution of their duties.

With the above mandate in mind and the forthcoming challenges of the twenty-first century, it is important to take a closer look at the principal and current constraints that educational institutions are facing and foresee the mechanisms that can facilitate them. A global assessment made by the World Bank (1988) identified some weaknesses that threaten the contribution of higher education to development. Based on my own experience in Latin American higher education systems, I agree with these assessments, including

a. The mix of outputs of higher education to development are no longer suited to the requirements for development;

b. The quality of those outputs show signs of deterioration;

c. costs of production are needlessly high; and

d. financing of the outputs is socially inequitable and economically inefficient. 
In the case of agriculture, van den Bor (1989) noted that agriculture is perceived as having a lower status, that the number of students enrolling in agricultural areas has significantly declined, while in Latin American countries, ironically, the key to economic development and mainstay of the population is the agricultural sector. Another weakness that can be added here is the limited participation of women in higher education due mainly to social barriers. These barriers can be removed if society provides equal opportunity to science education. A rural development project in agrosilvopastoral systems in Guatemala funded by the Canadian International Development Agency (1993) found that women played critical roles in the day-to-day activities both in the family and the farms, but were not recognized as decision makers by the local development agencies and therefore did not participate in the planning process.

What can be done to minimize the effects of the above-mentioned weaknesses? The author believes the following should be taken into account:

a. Take a critical look at the types of outputs that institutions must guarantee in their contributions to the developmental needs of society in the next century. This means that a well-devised medium term strategic plan should be developed.

b. Recognize the increasing need for institutional strategic alliances, be they south-south or north-south, to reduce cost and increase quality of output via complementarity of strengths. This will require a thorough analysis of the strengths and weaknesses of institutions that should be derived from the strategic plan.

c. Connect the curriculum with the research to ensure that the challenges faced by society are taken into account.

d. Structure outputs of institutions so that they are capable of handling global and international issues without regard to cultural, social and economic barriers, while at the same time allowing for the full participation of different sectors of society.

e. Create special institutional programs and opportunities to increase the participation of women in the process.

f. Develop international cooperation at the bilateral level and strengthen national institutions to facilitate sustainable development. 
The above imply that science education should undergo some important structural changes, such as those outlined by van den Bor (1989):

a. Establish mechanisms to increase the quality of outputs and the efficiency of producing outputs;

b. Constrain outputs, especially in fields that do not directly support economic development; and

c. Provide some relief to the public sector.

It should be noted that the structural adjustments suggested above are internal by nature; however, their effectiveness will depend on external factors such as changes in the policies.

\section{References}

ANUIES. 1994. La educación en México. Guadalajar, México.

CIDA/CATIE. 1992. Participación de la mujer en desarrollo. Informe del proyecto en Guatemala.

CATIE. 1992. Regional Program on Animal Genetic Conservation and Management. Edited by A. Tewolde. Turrialba, Costa Rica.

Hodges, John. 1985. Biotechnology. FAO Technical Publication. Rome, Italy. IFPRI. 1996. Feeding the World, Preventing Poverty, and Protecting the Earth: A 2020 Vision. Washington, D.C., U.S.A.

Keating, Michael. 1993. Programa para el Cambio, cumbre para la tierra. Nuestro futuro común.

Nuestro Futuro Común. 1993. El Programa 21 y los demás Acuerdos de Rio de Janeiro en versión simplificada. Gland, Suiza.

REDCA. 1994. Formación de los recursos humanos a nivel de posgrado ante los desafíos de los paradigmas del siglo XXI. Guatemala, Guatemala. Memoria de la Asamblea General de REDCA, Guatemala. "Formación de los recursos para el desarrollo sustentable."Editado por A. Tewolde.

Tewolde, A. 1993. El papel del profesional agrónomo en el siglo XXI. Congreso Mundial del Agrónomo. Santiago, Chile. (Memoria del Congreso pp. 6).

Van den Bor, Wont. 1989. Higher Agricultural Education Development. In: South-North partnership in strengthening higher education in agriculture. Eds. W. van den Bo, J. C. M. Shute, and G. A. B. Moore, Pudoc, Wageningen.

World Bank. 1988. World Bank Report 1987-1988. 